\title{
Ecological risk assessment of trace metals in the bottom sediments of the young water reservoir - Bardowskiego Lagoon (Warsaw) case study
}

\author{
Malwina Tytła ${ }^{1, *}$, Anna Dmochowska ${ }^{2}$, Dariusz Dmochowski ${ }^{3}$, and Kinga Jaworska ${ }^{2}$ \\ ${ }^{1}$ Institute of Environmental Engineering, Polish Academy of Sciences, M. Skłodowska-Curie St. 34, \\ 41-819 Zabrze, Poland \\ ${ }^{2}$ The Main School of Fire Service, Faculty of Fire Safety Engineering, Słowackiego St. 52/54, \\ 01-629 Warsaw, Poland \\ ${ }^{3}$ Warsaw University of Technology, Faculty of Building Services, Hydro and Environmental \\ Engineering, Nowowiejska St. 20, 00-653 Warsaw, Poland
}

\begin{abstract}
The aim of the study was to assess the ecological risk of five trace metals, i.e. $\mathrm{Cd}, \mathrm{Cu}, \mathrm{Ni}, \mathrm{Pb}, \mathrm{Zn}$, accumulated in bottom sediments of young water reservoir - Bardowskiego Lagoon located in Warsaw, Poland. In this case, several indices were used, i.e.: Geoaccumulation index (Igeo), Contamination factor (CF), Potential ecological risk factor (ER), Degree of contamination (DC), Pollution load index (PLI) and Risk index (RI). The average trace metals concentrations in sediments, were as follow: $\mathrm{Zn}>\mathrm{Pb}>\mathrm{Cu}>\mathrm{Cd}>\mathrm{Ni}$. The obtained results revealed that bottom sediments were very highly to extremely high contaminated by $\mathrm{Cd}$ and the ecological risk related with this pollutant was the largest. They also indicated that water from the study area was characterized by a low ecological quality, especially due to the content of $\mathrm{Cd}$ and $\mathrm{Pb}$. The research proves that problem of cadmium contamination in bottom sediments of young water reservoirs is real and poses a serious ecological risk.
\end{abstract}

\section{Introduction}

Bottom sediments constitute an integral part of the aquatic environment. They are also the final destination of trace metals as a result of i.a. adsorption, precipitation, diffusion processes, chemical reactions and biological activity [1-3]. There are two main sources of these pollutants in aquatic systems, i.e. natural (i.a. weathering of rocks and soils, erosion) and anthropogenic (i.a. industrial effluents, mining, agriculture drainage, domestic discharges and atmospheric deposition). However, in the majority they are of anthropogenic origin [4]. Trace metals may pose a serious threat to the aquatic environment and human health, due to their hazardous nature. Furthermore, they are toxic, resistant to biodegradation and have ability to bioaccumulate, increasing the exposure of living organisms through the trophic chain [5]. Therefore, it is important to assess the ecological risk caused by trace metals

\footnotetext{
*Corresponding author: malwina.tytla@ipis.zabrze.pl
} 
in bottom sediments, especially in those from young reservoirs, which are an integral part of ecological networks in urban areas.

The aims of this study were: (1) to investigate the concentration of trace metals $(\mathrm{Cd}, \mathrm{Cu}$, $\mathrm{Ni}, \mathrm{Pb}, \mathrm{Zn}$ ) in bottom sediments of the young water reservoir - Bardowskiego Lagoon and (2) to evaluate contamination degree and assess ecological risk posed by trace metals in bottom sediments, with use of various criteria, i.e. Geoaccumulation index ( $\mathrm{I}_{\mathrm{geo}}$ ) [6], Contamination factor (CF) [7], Potential ecological risk factor (ER), Degree of contamination (DC) [7], Pollution load index (PLI) [8] and Risk index (RI) [7].

\section{Materials and methods}

\subsection{Study area}

The Bardowskiego Lagoon is located in Warsaw, Targówek district $\left(52^{\circ} 16^{\prime} 09.3^{\prime \prime} \mathrm{N}\right.$ $21^{\circ} 05^{\prime} 56.2^{\prime \prime E}$ ), Central-Eastern Poland. It was put into use in 2015. The lagoon reaches two hectares, has a depth of $2 \mathrm{~m}$ and is fed by the Bródnowski Canal (Upper), which is located on the west side of the examined area. On the one side, the lagoon has a concrete wharf, while on the other it has a sandy beach with a fairly shallow descent. Bardowskiego Lagoon was created as part of a revitalization of the Bródnowski Canal and has a retention and recreational function. The lagoon is in close proximity to waste management plant (including hazardous waste), industrial buildings (gas bottling plant) and bus terminus, while the examined area is surrounded by forest from the south. The Bródnowski Canal was created in the second half of the $19^{\text {th }}$ century (length $-10.9 \mathrm{~km}$ ). It does not have any natural tributaries and is fed with rainwater discharged from two pumping stations and by water through drainage canals. In the past, it also received industrial sewage and slurry. Localization of Bardowskiego Lagoon is presented on Figure 1.

Due to the fact that the Bardowskiego Lagoon is fed with water from the Bródnowskiego Canal, it was assumed that they constitute one research object.

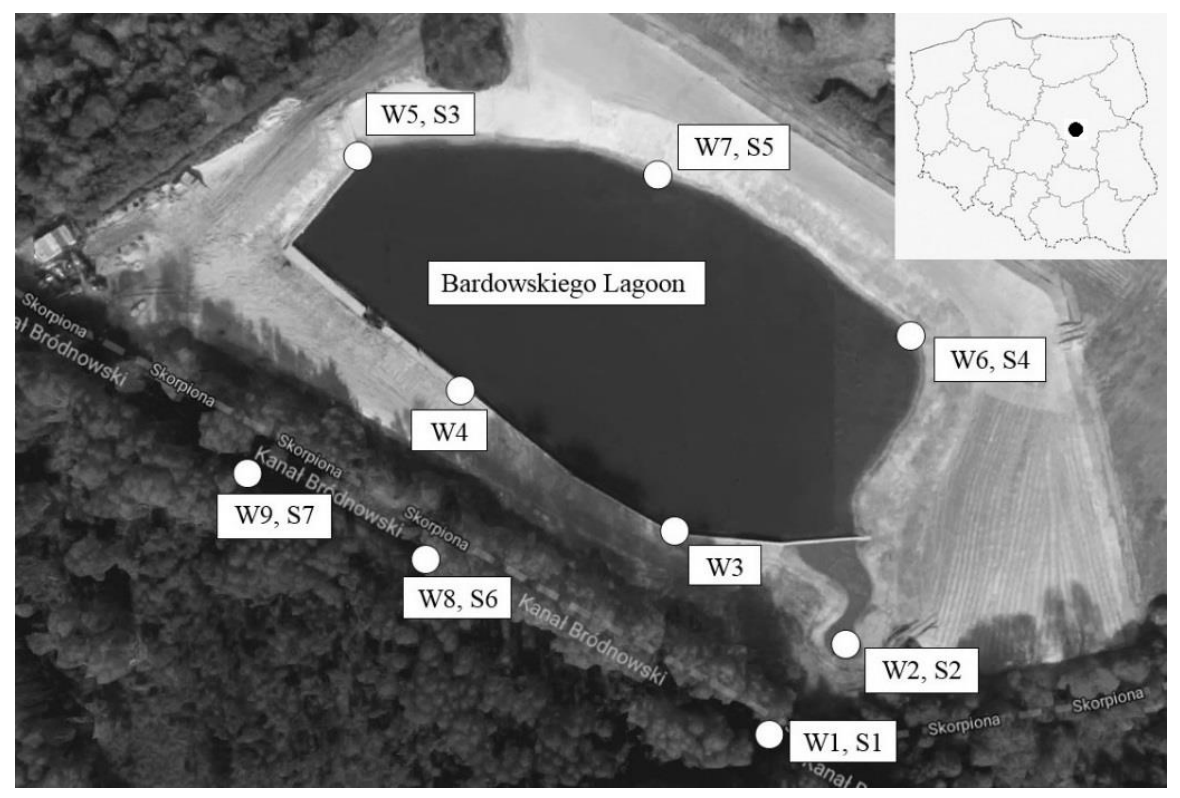

Fig. 1. Locations of Bardowskiego Lagoon and sampling sites. 


\subsection{Sample collection}

Water and sediment samples from the examined area were collected in April 2017. Sediments samples were collected from the surface layer $(0-5 \mathrm{~cm})$, at 7 sampling sites. Four sampling sites were located around the Bardowskiego Lagoon (S2-S5) and three along the Bródnowskiego Canal (S1, S6, S7). Whereas water samples were collected from the depth of 20-50 cm below water table, at 9 sampling sites. Six of them were located around the Bardowskiego Lagoon (W2-W7) and three along the Bródnowskiego Canal (W1, W8, W9) (Fig. 1). All samples were stored in polypropylene tubes and kept in refrigerator at $4{ }^{\circ} \mathrm{C}$, until the processing and analysis.

\subsection{Determination of trace metals concentrations}

The sediment samples included: initial drying for 48 hours at $20^{\circ} \mathrm{C}$ until air - dry, then to constant mass at $105^{\circ} \mathrm{C}$ and milling to obtain the analytical grain $(<2 \mathrm{~mm})$. Subsequently samples were subjected to mineralization. For this purpose $0.5 \mathrm{~g}$ of sediment sample was weighted to PTFE vessels and digested with $9 \mathrm{~cm}^{3} \mathrm{HNO}_{3}$ and $3 \mathrm{~cm}^{3} \mathrm{HClO}_{4}$. Obtained solutions were filtered through the fine filters $(0.45 \mu \mathrm{m})$ and dissolved with $2 \% \mathrm{HNO}_{3}$ to volume of $50 \mathrm{ml}$. In the mineralized samples metals contents were measured by flame atomic absorption spectrometry technique, using Solar 969 with graphite furnace atomic absorption (GFAA). Instrument settings were as recommended in the manufacturer's manual, with wave - lengths (nm) of: $228.8(\mathrm{Cd}), 324.8(\mathrm{Cu}), 232.0(\mathrm{Ni}), 217.0(\mathrm{~Pb})$ and $231.9(\mathrm{Zn})$. All the standards were prepared on the day the analysis was performed.

Metals concentrations in water samples were measured identically to the sediments, by omitting the mineralization stage. Water samples were filtered through the the fine filters $(0.45 \mu \mathrm{m})$, prior to AAS analysis.

\subsection{The ecological risk assessment}

Ecological risk assessment of selected metals in bottom sediment were calculated by the equations shown in Table 1. The calculations take into account various concentrations of individual trace metals in the Earth's crust, according to the literature data [6-8].

\subsection{Statistical analysis}

The statistical analyses were performed with Statistica ver. 12.0 software. In order to identify the relationships between analysed parameters in water an sediment samples, Spearman's rank correlation coefficient and Mann-Whitney $U$ test were used (significant at $p<0.05$ ). Data analysis including also: mean, minimum, maximum and standard deviation (SD). 
Table 1. The criteria of contamination and ecological riskassessment of trace metals in sediments.

\begin{tabular}{|c|c|c|c|}
\hline $\begin{array}{c}\text { Classifications and } \\
\text { indices }\end{array}$ & Equation with description & Category & Description of category \\
\hline $\begin{array}{l}\text { Geoaccumulation } \\
\text { index }\left(I_{\mathrm{geo} o}\right)[6]\end{array}$ & $\begin{array}{c}I_{\mathrm{geo}}=\log _{2}\left(C_{\mathrm{n}} / 1.5 B_{\mathrm{n}}\right)(1) \\
C_{n}-\text { measured concentration } \\
\text { of element in the sediment } \\
\text { sample; } B_{\mathrm{n}}-\text { geochemical } \\
\text { background value in Earth's } \\
\text { crust }[9-11]\end{array}$ & $\begin{array}{c}I_{\mathrm{geo}} \leq 0 \\
0<I_{\mathrm{geo}} \leq 1 \\
1<I_{\text {geo }} \leq 2 \\
2<I_{\text {geo }} \leq 3 \\
3<I_{\text {geo }} \leq 4 \\
4<I_{\text {geo }} \leq 5 \\
5<I_{\text {geo }}\end{array}$ & $\begin{array}{c}\text { Practically } \\
\text { uncontaminated } \\
\text { Uncontaminated to } \\
\text { Moderately } \\
\text { Moderately } \\
\text { Moderately to Heavily } \\
\text { Heavily contaminated } \\
\text { Heavily to Extremely } \\
\text { Extremely contaminated }\end{array}$ \\
\hline $\begin{array}{l}\text { Contamination } \\
\text { factor }(C F)[7]\end{array}$ & $\begin{array}{l}\quad C F=\sum C_{1} / C(2) \\
C_{1}-\text { mean content of elements } \\
\text { from at list five sampling sites; } \\
C=\left(B_{\mathrm{n}}\right)-\text { concentration of } \\
\text { metals in the Earth's crust }\end{array}$ & $\begin{array}{c}C F<1 \\
1<C F<3 \\
3<C F<6 \\
\quad C F>6\end{array}$ & $\begin{array}{c}\text { Low contamination } \\
\text { Moderate } \\
\text { Considerable } \\
\text { Very high contamination }\end{array}$ \\
\hline $\begin{array}{l}\text { Potential ecological } \\
\text { risk factor }(E R) \text { [7] }\end{array}$ & $\begin{array}{c}E R=T \cdot C F(3) \\
T-\text { toxic response factor of } \\
\text { element; } C F-\text { contamination } \\
\text { factor }\end{array}$ & $\begin{array}{c}E R<40 \\
40<E R \leq 80 \\
80<E R \leq 160 \\
160<E R \leq 320 \\
E R>320\end{array}$ & $\begin{array}{c}\text { Low risk } \\
\text { Moderate risk } \\
\text { Considerable risk } \\
\text { High risk } \\
\text { Very high risk }\end{array}$ \\
\hline $\begin{array}{c}\text { Degree of } \\
\text { contamination }(D C) \\
{[7]}\end{array}$ & $\begin{array}{c}D C=\sum C F(4) \\
C F-\text { Contamination factor }\end{array}$ & $\begin{array}{c}C D<6 \\
6<C D \leq 12 \\
12<C D \leq 24 \\
C D>24\end{array}$ & $\begin{array}{l}\text { Low degree of } \\
\text { contamination } \\
\text { Moderate degree } \\
\text { Considerable degree } \\
\text { Very high degree }\end{array}$ \\
\hline $\begin{array}{l}\text { Pollution load } \\
\text { index }(P L I)[8]\end{array}$ & $\begin{array}{c}P L I=\left(C F_{1} \cdot C F_{2} \cdot C F_{3} \cdot C F_{\mathrm{n}}\right)(5) \\
C F_{\mathrm{n}}-C F \text { value of element } n\end{array}$ & $\begin{array}{l}P L I>1 \\
P L I<1\end{array}$ & $\begin{array}{l}\text { Polluted } \\
\text { Unpolluted }\end{array}$ \\
\hline Risk index $(R I)[7]$ & $\begin{array}{c}R I=\sum E R(6) \\
E R-\text { potential ecological risk } \\
\text { factor }\end{array}$ & $\begin{array}{c}R I<150 \\
150<R I<300 \\
300<R I<600 \\
R I>600\end{array}$ & $\begin{array}{c}\text { Low risk } \\
\text { Moderate risk } \\
\text { Considerable risk } \\
\text { High risk }\end{array}$ \\
\hline
\end{tabular}

\section{Results and discussion}

\subsection{Trace metals in water and bottom sediments}

Table 2 and 3 presents values of metals concentrations in water and sediment samples from the study area. The content of examined trace metals in water varies from: $1.9-4.1 \mu \mathrm{g} / \mathrm{dm}^{3}$, $4.2-6.5 .5 \mu \mathrm{g} / \mathrm{dm}^{3}, 2.8-4.4 .1 \mu \mathrm{g} / \mathrm{dm}^{3}, 8.4-15.4 \mu \mathrm{g} / \mathrm{dm}^{3}, 28.7-55.6 \mu \mathrm{g} / \mathrm{dm}^{3}$, to $\mathrm{Cd}, \mathrm{Cu}, \mathrm{Ni}$, $\mathrm{Pb}$ and $\mathrm{Zn}$, respectively. Studies have shown that the concentration of $\mathrm{Cd}$ and $\mathrm{Pb}$ at all sampling sites exceeded the limit values, included in Regulation of the Minister of the Environment of $21^{\text {st }}$ July 2016 [12]. This indicated that water from the study area is characterized by a low ecological quality, due to the high content of cadmium and lead.

The ranges of trace metals in sediment samples were: $1.4-10.6 \mathrm{mg} / \mathrm{kg}_{\mathrm{DM}}$, $1.7-12.8 \mathrm{mg} / \mathrm{kg}_{\mathrm{DM}}, 1.1-7.9 \mathrm{mg} / \mathrm{kg}_{\mathrm{DM}}, 4.9-39.1 \mathrm{mg} / \mathrm{kg}_{\mathrm{DM}}, 10.4-94.8 \mathrm{mg} / \mathrm{kg}_{\mathrm{DM}}$, to $\mathrm{Cd}, \mathrm{Cu}, \mathrm{Ni}$, 
$\mathrm{Pb}$ and $\mathrm{Zn}$, respectively. The average concentration of selected trace metals in sediment samples exceeded the geochemical background levels. It was found that according to Geochemical quality classification (GQC), bottom sediments are contaminated by Cd (IV class; highly contaminated) and $\mathrm{Pb}$ (II class; moderately contaminated) [13]. The average trace metals concentrations in sediments, were as follow: $\mathrm{Zn}>\mathrm{Pb}>\mathrm{Cu}>\mathrm{Cd}>\mathrm{Ni}$. In comparison, in other anthropogenic reservoirs in Poland and abroad, the average concentrations of metals in sediments showed the following trend: $\mathrm{Zn}>\mathrm{Pb}>\mathrm{Cr}>\mathrm{Cu}>\mathrm{Cd}$ [14], $\mathrm{Zn}>\mathrm{Cu}>\mathrm{Pb}>\mathrm{Cr}>\mathrm{Ni}>\mathrm{Cd}$ [2], and $\mathrm{Zn}>\mathrm{As}>\mathrm{Sb}>\mathrm{Pb}>\mathrm{Cd}$ [15]. It should be emphasized, that the levels of cadmium in sediments of water reservoirs have been the focus of concern due to its high toxicity $[16,17]$. Moreover, cadmium is also one of the most labile metals in environment [16]. Thus, the regular monitoring of its content in the aquatic systems is necessary, especially in bottom sediments of the young water reservoirs, which have various functions, such as recreation and are located in industrialised and urbanised areas with high population density [17].

The highest concentrations of trace metals in water and sediment samples were observed at the W9, S7 (canal) and W6, S4 (lagoon) sampling sites. Based on the SD values, it can be stated that concentration of $\mathrm{Zn}$ was characterized by the greatest variability, while Ni by the lowest, for both water and sediment samples. The research also indicated that contents of metals decreased along with the distance from the estuary to the Bródnowskiego Canal. The most probable reason for the lower content of examined metals in water and sediment samples from the Bardowskiego Lagoon - is his young age (about 3 years). It can be assumed that the metals present in water of the canal have not yet fully accumulated in sediments of the lagoon.

Table 2. Contents of metals in water samples $\left(\mu \mathrm{g} / \mathrm{dm}^{3}\right)$.

\begin{tabular}{|c|c|c|c|c|c|c|c|c|c|c|c|}
\hline Metal & $*$ W1 & W2 & W3 & W4 & W5 & W6 & W7 & $*$ W8 & $*$ W9 & Mean & SD \\
\hline $\mathbf{C d}$ & 3.5 & 2.9 & 1.9 & 2.5 & 2.5 & 2.1 & 2.6 & 2.9 & 4.1 & 2.8 & 0.7 \\
\hline $\mathbf{C u}$ & 6.5 & 5.3 & 4.9 & 4.7 & 4.6 & 4.2 & 5.5 & 5.5 & 4.8 & 5.1 & 0.7 \\
\hline $\mathbf{N i}$ & 4.2 & 4.1 & 4.4 & 3.9 & 3.3 & 2.8 & 4.4 & 4.3 & 4.2 & 4.0 & 0.6 \\
\hline $\mathbf{P b}$ & 12.6 & 10.2 & 9.8 & 11.3 & 8.4 & 13.1 & 12.3 & 14.2 & 15.4 & 11.9 & 2.2 \\
\hline $\mathbf{Z n}$ & 35.6 & 31.6 & 33.1 & 28.7 & 40.5 & 30.8 & 36.4 & 45.1 & 55.6 & 37.5 & 8.5 \\
\hline
\end{tabular}

*Samples from the Bródnowskiego Canal

Table 3. Contents of metals in sediment samples ( $\left.\mathrm{mg} / \mathrm{kg}_{\mathrm{DM}}\right)$.

\begin{tabular}{|c|c|c|c|c|c|c|c|c|c|}
\hline Metal & $*$ S1 & S2 & S3 & S4 & S5 & $*$ S6 & $*$ S7 & Mean & SD \\
\hline $\mathbf{C d}$ & 8.6 & 2.9 & 1.4 & 9.6 & 2.8 & 8.9 & 10.6 & 6.4 & 3.9 \\
\hline $\mathbf{C u}$ & 10.2 & 3.8 & 1.7 & 10.4 & 3.2 & 10.6 & 12.8 & 7.5 & 4.5 \\
\hline $\mathbf{N i}$ & 6.2 & 2.1 & 1.1 & 6.2 & 1.9 & 6.4 & 7.9 & 4.5 & 2.7 \\
\hline $\mathbf{P b}$ & 39.6 & 12.5 & 4.9 & 27.9 & 8.7 & 34.8 & 39.1 & 23.9 & 14.9 \\
\hline $\mathbf{Z n}$ & 99.3 & 33.5 & 10.4 & 72.8 & 22.4 & 84.8 & 94.8 & 59.7 & 36.8 \\
\hline
\end{tabular}


Spearman's rank correlation coefficient between the studied variables indicated that there were no significant correlation between the concentrations of trace metals in water samples, in except for $\mathrm{Cd}$ and $\mathrm{Zn}$. This may indicate that examined pollutants originate from natural source or were introduced into water as a poorly soluble compounds, and thus may also be associated with emissions from mechanical processes. Both in minerals and sand, as well as in particles from tire abrasion and road surfaces, metals are bound in poorly water soluble compounds [18].

The statistical analysis also revealed a strong positive correlation between the contents of all examined trace metals in sediment samples. This indicate that they may derive from similar source or have the similar accumulation behavior [2]. Our observations were confirmed by other scientists who also found a strong positive correlation between various metals in bottom sediments of water reservoirs in China [19].

The results of Mann - Whitney U test indicated that there were no significant differences between the levels of water and sediments pollution. Therefore, it can be assumed that accumulation level of trace metals in sediments from study area is not enough to treat it as a historical one. It probably changes over time, like the level of water pollution and depends on the sources, which are currently affecting the reservoir, i.e. their type and intensity of emission.

\subsection{The ecological risk assessment}

The ecological risk assessment of trace metals in bottom sediments of the Bardowskigo Lagoon were calculated by the equations shown in Table 4. In this purpose, two groups of indices were used: relating to a single metal ( $\mathrm{I}_{\text {geo }}, \mathrm{CF}$, ER; single metal - indices) and to a group of metals (DC, PLI, RI; multi - metal indices). This approach allows to evaluate the level of contamination, which constitute an integral part of ecological risk assessment, resulting from the presence of metals in bottom sediments. The conducted research revealed that the major pollutant of sediments is cadmium, which posed the highest ecological risk. It was found that sediments were also moderately to highly contaminated by $\mathrm{Pb}$ and $\mathrm{Zn}$ (according to CF values), which in fact had minor effect on the final levels of computed risks. However, there were practically no differences in the obtained results, irrespectively of average content of individual trace metals in the Earth's crust [6-8]. The computed $\mathrm{I}_{\text {geo }}$ and $\mathrm{CF}$ values indicated that bottom sediments from the study area were heavily to extremely ( $\left.\mathrm{I}_{\text {geo }}\right)$ and very highly $(\mathrm{CF})$ contaminated with $\mathrm{Cd}$, which. cause very high ecological risk (ER), both to aquatic environment and living organisms (including humans). Furthermore, it was found that sediments with $\mathrm{Cu}$ and $\mathrm{Ni}$ contents did not pose any ecological risk. The conducted research has also shown that both contamination and ecological risk levels, for single trace metal in examined sediments were as follow: $\mathrm{Cd}>\mathrm{Pb}>\mathrm{Zn}>\mathrm{Cu}>\mathrm{Ni}$. In comparison, other scientists found that $\mathrm{I}_{\text {geo }}$ values of selected metals in sediments from the example water bodies, decreased generally in the order of: $\mathrm{Cd}>\mathrm{Cu}>\mathrm{Ni}>\mathrm{Pb}>\mathrm{Zn}$ and $\mathrm{Cd}$ $>\mathrm{Hg}>\mathrm{Cu}>\mathrm{Zn}>\mathrm{Ni}>\mathrm{Pb}>\mathrm{As}>\mathrm{Cr}[20,21]$. Moreover, there are research data, which indicate that sediments from the various water reservoirs are classified as moderately to very highly contaminated with cadmium $(\mathrm{CF}>6)$, i.a. in Slovakia [22] and Poland [14]. Furthermore, there are also studies which confirmed that $\mathrm{Cd}$ pose the highest ecological risk in bottom sediments $(\mathrm{ER}=218.1)$ [21], which is in a good agreement with results presented in this work. The multi - metal indices, i.e. DC, PLI and RI, were introduced to estimate the overall levels of contamination and ecological risk at given sampling site. The obtained results revealed that the highest contamination and ecological risk occurred at sampling site S7 (located farthest from the canal), while the lowest at S3. The average DC (69.2; 66.1; $66.8)$ and PLI $(1.0 ; 1.7 ; 1.2)$ values - computed according to various concentrations of individual trace metals in the Earth's crust [9-11], indicated that bottom sediments were 
generally very highly polluted with examined metals, especially by $\mathrm{Cd}$. The only exception constituted sediments collected at sampling sites S2, S3 and S5, where the lowest concentrations of all examined metals were detected. The similar observation was made in case of ecological risk expressed as RI, which avareage values $(1971.7 ; 1894.4 ; 1930.6)$ indicated high risk due to the presence of examined trace metals in the bottom sediments of the study area. The results obtained in this work were also confirmed by other researchers. Fot example, it was shown based on the DC values, that sediments from selected water reservoirs in Slovakia were classified as very highly contaminated with $\mathrm{Cu}, \mathrm{Zn}, \mathrm{As}, \mathrm{Cd}, \mathrm{Pb}$ [22]. Whereas, other scientist found that PLI in selected sediments ranged from 0.24-1.25, with mean value 0.59 [23]. There are also studies, which confirmed the existence of high ecological risk ( $\mathrm{RI}$ from 37.2 to 409.5 ) due to the presence of selected metals, i.e. $\mathrm{Cu}, \mathrm{Ni}, \mathrm{Pb}$, $\mathrm{Zn}, \mathrm{Cd}$ and $\mathrm{Cr}$ in the bottom sediments [20].

Table 4. The ecological risk assessment of trace metals (bold - indicates the highest levels).

\begin{tabular}{|c|c|c|c|c|c|c|c|}
\hline $\mathrm{B}_{\mathrm{n}}$ & Metal & Igeo & CF & ER & DC & PLI & RI \\
\hline${ }^{1} 0.098$ & $\mathrm{Cd}$ & $3.3-6.2$ & $14.3-108.2$ & $\begin{array}{l}428.6- \\
3244.9\end{array}$ & \multirow{5}{*}{$\begin{array}{l}16.1- \\
114.5 \\
(69.2)\end{array}$} & \multirow{5}{*}{$\begin{array}{c}0.2-1.5 \\
(\mathbf{1 . 0})\end{array}$} & \multirow{5}{*}{$\begin{array}{c}431.9- \\
3271.7 \\
(1971.7)\end{array}$} \\
\hline 75 & $\mathrm{Cu}$ & $(-6.0)-(-3.1)$ & $0.1-0.2$ & $0.1-0.9$ & & & \\
\hline 105 & $\mathrm{Ni}$ & $(-7.2)-(-4.3)$ & 0.1 & $0.1-0.4$ & & & \\
\hline 8 & $\mathrm{~Pb}$ & $(-1.3)-1.7$ & $0.6-5.0$ & $3.1-24.8$ & & & \\
\hline 80 & $\mathrm{Zn}$ & $(-3.5)-(-0.3)$ & $0.1-1.2$ & $0.1-1.2$ & & & \\
\hline${ }^{2} 0.102$ & $\mathrm{Cd}$ & $3.2-6.1$ & $13.7-103.9$ & $\begin{array}{l}411.8- \\
3117.6\end{array}$ & \multirow{5}{*}{$\begin{array}{l}14.4- \\
109.4 \\
(66.1)\end{array}$} & \multirow{5}{*}{$\begin{array}{c}0.4-2.8 \\
(1.7)\end{array}$} & \multirow{5}{*}{$\begin{array}{c}414.3- \\
3137.6 \\
(1894.4)\end{array}$} \\
\hline 14.3 & $\mathrm{Cu}$ & $(-3.7)-(-0.7)$ & $0.1-0.9$ & $0.6-4.5$ & & & \\
\hline 18.6 & $\mathrm{Ni}$ & $(-4.7)-(-1.8)$ & $0.1-0.4$ & $0.3-2.1$ & & & \\
\hline 17 & $\mathrm{~Pb}$ & $(-2.4)-(-0.6)$ & $0.3-2.3$ & $1.4-11.5$ & & & \\
\hline 52 & $\mathrm{Zn}$ & $(-2.9)-0.3$ & $0.2-1.9$ & $0.2-1.9$ & & & \\
\hline${ }^{3} 0.1$ & $\mathrm{Cd}$ & $4.2-6.1$ & 14.0 - 10.6 & $\begin{array}{l}420.0- \\
3180.0\end{array}$ & \multirow{5}{*}{$\begin{array}{l}14.6- \\
110.6 \\
(66.8)\end{array}$} & \multirow{5}{*}{$\begin{array}{c}0.3-\mathbf{2 . 0} \\
(\mathbf{1 . 2})\end{array}$} & \multirow{5}{*}{$\begin{array}{c}422.2- \\
3197.5 \\
(1930.6)\end{array}$} \\
\hline 55 & $\mathrm{Cu}$ & $(-5.6)-(-2.7)$ & $0.1-0.2$ & $0.2-1.2$ & & & \\
\hline 20 & $\mathrm{Ni}$ & $(-1.9)-0.8$ & $0.1-0.4$ & $0.3-2.0$ & & & \\
\hline 15 & $\mathrm{~Pb}$ & $(-2.2)-0.8$ & $0.3-2.6$ & $1.6-13.2$ & & & \\
\hline 70 & $\mathrm{Zn}$ & $(-3.3)-(-0.1)$ & $0.3-1.4$ & $0.1-1.4$ & & & \\
\hline
\end{tabular}

${ }^{1}[9],{ }^{2}[10],{ }^{3}[11]$ 


\section{Conclusions}

The conducted research indicated that even in young water reservoirs, there is a possibility of high contamination of sediments with trace metals, which can result in serious ecological risk, for both aquatic environment and living organisms, including human populations. This issue is of great importantce to water reservoirs, which are an integral part of ecological networks in urban areas. It should be also emphasized that properties of metals, i.e. their concentrations, time of exposure and toxicity are still the most important indicators of aquatic environments quality.

The data used in the paper come from the studies carried out for the MSc thesis written by Kinga Jaworska under supervision of Prof Wioletta Rogula - Kozłowska at The Main School of Fire Service, Faculty of Fire Safety Engineering (Warsaw).

\section{References}

1. A.J. Turki, JKAU: Mar. Sci. 18 (2007)

2. A. Baran, M. Tarnawski, T. Koniarz, Environ. Sci. Pollut. Res. 23, 17 (2016)

3. I. Cymes, K. Glińska-Lewczuk, S. Szymczyk, M. Sidoruk, A. Potasznik, J. Elem. 22, 3 (2017)

4. S. Sobhanardakani, M. Ghoochian, Int. J. Toxicol. 10, 4 (2016)

5. P. Palma, L. Ledo, P. Alvarenga, Catena, 128 (2015)

6. G. Muller, Geo Journal 2, 3 (1969)

7. L. Hakanson, Water Res. 14, 8 (1980)

8. D.L. Tomlinson, J.G. Wilson, C.R. Harris, D.W. Jeffrey, Helgol. Wiss. Meeresunlter, 33, 1-4 (1980)

9. S.R. Taylor, S.M. McLennan, Rev. Geophys. 33 (1995)

10. K.H. Wedepohl, Geochim Cosmochim Acta, 59, 7 (1995)

11. A. Kabata-Pendias, Trace elements in soils and plants $\left(4^{\text {th }}\right.$ ed. New York: Taylor \& Francis, London, 2011)

12. Regulation of the Ministerof the Environmentof $21^{\text {st }}$ July 2016 on the classification method for the conditionof bodiesofsurface waters and environmental quality standards for the priority substances (Journal of Laws item 1187)

13. I. Bojakowska, Polish Geological Review 49, 3 (2001)

14. G. Zemełka, E. Szalińska, Engineering and Protection of Environment 20, 1 (2017)

15. Y. Liu, X. Zhou, X. Wang, Q. Liu, P. Zhu, L. Zhang, C. Sun, Pol. J. Environ. Stud. 26, 1 (2017)

16. M. Saleem, J. Iqbal, M.H. Shah, Environ. Nano. Monit. Manag. 4 (2015)

17. M.A. Rzętała, J. Soils Sediments, 16 (2016)

18. W.A. Birmili, G. Allen, F. Bary, R.M. Harrison, Environ. Sci. Technol. 40, 4 (2006)

19. X.Wei, L.Han, B.Gao, H.Zhou, J.Lu, X.Wan, Ecol. Indic. 61, 2 (2016)

20. Z. Wang, R. Sun, H. Zhang, L. Chen, Front. Environ. Sci. Eng. 9, 2 (2015)

21. Y. Xu, Y. Wu, J. Han, P. Li, Ecol. Evol. 7 (2017)

22. E. Singovszka, M. Balintova, M. Holub, Journal of the Polish Mineral Engineering Society, 15 (2014)

23. S. Sivakumar, A. Chandrasekaran, G. Balaji, R. Ravisankar, J. Heavy Metal Toxicity Dis. 1, 2-11 (2016) 